In the visceral arteries, prazosin (40 and $80 \mathrm{nmol} / \mathrm{l}$ ) produced a dose-dependent parallel shift in the noradrenaline dose-response curves, thus acting as a competitive alphaadrenoceptor antagonist. In the peripheral arteries, however, the same concentrations did not significantly shift the curves, and the maximum response to noradrenaline was only slightly reduced. This appeared to be the maximum effect of prazosin in the digital arteries as a higher concentration $(320 \mathrm{nmol} / \mathrm{l})$ caused no further shift of the curves or reduction in the maximum response to noradrenaline.

This lack of effect of prazosin was not due to an inability of the peripheral arteries to respond to competitive antagonists, since phentolamine produced typical dose-dependent shifts of the noradrenaline response curves.

These results suggest that in concentrations resembling therapeutic plasma levels, prazosin acts as a competitive alphaadrenoceptor antagonist, rather than a direct arterial smoothmuscle relaxant. Secondly, that prazosin has a selective effect on different vascular beds, the visceral vascular bed being sensitive and the peripheral vascular bed resistant to its sympatholytic activity.

We suggest that cardiovascular collapse caused by prazosin is due to selective blockade of visceral sympathetic activity. The consequent pooling of blood in the viscera then leads to a redistribution of blood volume which in some patients is sufficiently severe to cause an acute hypovolæmic state and cardiovascular collapse.

Department of Medicine,

Victoria 3050, Australia

R. F. W. MOULDS

R. A. JACERNIG

\section{BLOOD/BRAIN BARRIER AND BRAIN CEDEMA IN AMMONIA INTOXICATION}

SIR,-Episodes of very high intracranial pressure have been recorded in patients with hepatic encephalopathy, Reye's syndrome, and mushroom poisoning. ${ }^{1-3}$ Ammonia intoxication has often been considered the cause of encephalopathy in these conditions. Studies in the monkey showed that increased blood-ammonia levels are accompanied by massive increases in intracranial pressure. The cause of such increases in intracranial pressure has been thought to be cerebral cedema.

To investigate further the mechanisms involved, bloodammonia levels in healthy cats were raised to values similar to those sometimes seen clinically by slow continuous intravenous infusion of ammonium acetate. All animals were paralysed and mechanically normoventilated under barbiturate anæsthesia. Systemic arterial pressure (femoral artery), cerebrospinal-fluid pressure (cisterna magna), and bilateral brain-tissue pressure (internal capsules) ${ }^{5}$ were continuously monitored. Bloodammonia levels as well as arterial $\mathrm{PCO}_{2}$ were monitored. After the animals' death, the integrity of the blood/brain barrier was checked by searching for extravasation of Evans blue which had been injected earlier. Brain tissue water content was determined gravimetrically. ${ }^{\circ}$

Ammonia infusion led to increases in intracranial pressure in all animals, and caused death in most of them. In no animal did we observe extravasation of Evans blue except at sites where brain tissue herniation had taken place (e.g., foramen magnum). In no animal did we observe brain cedema as defined by an increase in tissue water content.

Kind, G. W., Waldman, J., Kohl, S., Baublis, J., Tucker, R. P. f. Am. med. Ass. 1975, 231, 822.

2. Chandler, W. F., Kindt, G. W. Surg. Neurol. 1976, 5, 311

Kindt, G. W, Chandler, W. F., Gosch, H. H. in Intracranal Pressure III (edited by J. Beks, A. Bosch, and M. Brock); p. 331. Berlın, 1976.

4. Altenau, L L., Kındt, G. W., Chandler, W. F. Surg. Forum, 1976, 27, p. 490.

Brock, M., Winkelmưller, W., Poll, W., Markakis, E., Dietz, H. Lancet, $1972,1,595$

6. Varmarou, A., Shapiro, K., Poll, W., Shulman, K. in Intracranial Pressure III (edited by J. Beks, A. Bosch, and M Broch); p. 1. Berlın, 1976.
Our observations suggest that the massive rises in intracranial pressure seen in ammonia intoxication may be due to an increased intracranial blood volume caused by impairment of autoregulation leading to vasodilatation. We do not know whether this impairment of autoregulation is due to a direct toxic action of ammonia on autoregulatory mechanisms of the vessel wall or on metabolic processes within the brain tissue.

Neurosurgical Unıt,

Hannover Medical School,

Hannover, Federal Republic of Germany, and Section of Neuro Surgery,

Unuversity of Michigan Medical Center, Ann Arbor, Michigan, U.S.A.

G. W. KINDT

M. BROCK

L. L. Altenau W. PƠLL

\section{GRENADE SPLINTER CAUSING BILIARY COLIC}

SIR, - A 57-year-old physician was wounded by grenade splinters in 1942. According to the patient one of these lodged in the right lung near the diaphragm. By 1965 this piece of metal had pervaded the diaphragm and caused a subphrenic abscess which was drained without removal of the splinter. Apart from epidemic hepatitis in 1945 the patient had had no other serious illnesses.

A stomach X-ray in March, 1975, revealed a foreign body in the left hepatic lobe at the height of $\mathrm{T} 10$.

Since early summer, 1976, the patient had frequent colic in the right hypochondrium with occasional short periods of mild jaundice of the scleras and dark urine. Among the laboratory findings during these attacks were raised serum alkaline phosphatase, transaminases, and $\gamma$-glutamyl transpeptidase (G.G.T.); serum-bilirubin only once slightly raised; serum-amylase always normal. Between these periods the patient felt well for 2-3 weeks, and, except for a raised G.G.T., laboratory tests were normal.

though an oral cholecystography did not suggest gallston: $s$ hypotonic duodenography revealed a piece of metal in the common bileduct at the ampulla of Vater, causing an inflammatory reaction in the adjoining duodenum.

The foreign body, measuring $14 \times 8 \mathrm{~mm}$, was surgically removed from the common bileduct on Oct. 151976 . The left hepatic lobe was atrophied, and liver tissue had been replaced by connective tissue. A wide bileduct led from this area to the common duct, and this was the way the splinter had descended to the ampulla of Vater.

Similar sequelæ of grenade splinter injuries have been reported by Schenk, Jänike, and Wolf and Kynast. ${ }^{1-4}$ They were associated with colic, fever, or jaundice. Mörl's patient ${ }^{2}$ was treated as having hepatitis until a splinter was found at the confluence of the hepatic duct. In these reports the interval between injury and biliary symptoms was between 14 and 26 years. The time interval in our case was 34 years.

Although biliary colic caused by foreign bodies is very rare, it should be considered when the patient has a history of injury of this sort.

Departments of Internal Medicine and Surgery, University of Innsbruck, Innsbruck, A6020 Austria

H. P. RHOMBERG G. JUDMAIR E. BODNER

\section{LYMPHOMAS AND ANIMAL-PROTEIN CONSUMPTION}

SIR,-Dr Garwicz's hypothesis' that low intake of animal protein diminishes the frequency of acute leukæmia in children calls to mind similar findings in a different tumour/host system. Anderson et al. ${ }^{\circ}$ noted that the telative frequencies cat-

1. Jänke, E. $Z$ bl. Chir. 1960, 32, 1644

2. Mörl, F. K. ibid. 1966, 47, 1751 .

3. Schenk, E. ibid. 1968, 43, 1521.

4. Wolf, W., Kynast, J. ibud. 1975, 100, 1129.

5. Garwicz, S. Lancet, 1976, 11, 1413.

6. Anderson, D. E., Pope, L. S., Stephens, S. J. natn. Cancer Inst. 1970, 45, 697. 